\title{
FROM THE MARGINS TO THE MAINSTREAM: INDIGENISED DEVELOPMENT IN BORNEO WITH INFORMATION AND COMMUNICATION TECHNOLOGIES AND ITS CONTRIBUTION TO GLOBAL SUSTAINABLE DEVELOPMENT
}

\author{
Poline Bala* \\ Institute of Borneo Studies, Universiti Malaysia Sarawak \\ Narayanan Kulathu Ramaiyer \\ Institute of Social Informatics and Technological Innovations, Universiti Malaysia Sarawak \\ Roger W. Harris \\ Senior Research Fellow, Universiti Malaysia Sarawak \\ Corresponding author $(*)$ : Poline Bala (bpoline@unimas.my)
}

\begin{abstract}
The introduction of Information and Communication Technologies (ICTS) to remote and isolated indigenous communities in the forested interior of Borneo has generated desirable development benefits for them as well as revealing the processes of community engagement that were necessary for bringing them about. Associated learning has also highlighted aspirations for development that relate to the specifics of their cultures and lifestyles in relation to the natural environment in which they live, lending credence to the concept of ethno or indigenised development in contrast to notions of asset exploitation expressed within orthodox development. The emergence of the global Sustainable Development Goals (SDGs) with their imperatives for protecting biodiversity and the rainforests as well as combatting climate change focusses greater attention on the role of indigenous peoples as stewards of fragile ecosystems that are highly susceptible to global warming. The experiences of applying ICTs to indigenised development within Borneo's rainforest communities - helping them maintain eco-friendly lifestyles, conserve biodiversity and record their traditional knowledge about the climate - carries lessons of global significance for the wider achievement of the SGDs and the future of our planet.
\end{abstract}

Keywords: Indigenous peoples, sustainable development, Borneo

Copyright: This is an open access article distributed under the terms of the Creative Commons Attribution-NonCommercialShareAlike 4.0 International (CC BY-NC-SA 4.0) license which permits unrestricted use, distribution, and reproduction in any medium, for non-commercial purposes, provided the original work is properly cited.

\section{INTRODUCTION}

According to the World Bank, there are approximately 476 million Indigenous Peoples worldwide living in more than 90 countries. Although comprising a little more than 6 percent of the global population, they account for about 15 percent of the world's extreme poor. The Bank points out that Indigenous Peoples are distinct social and cultural groups that share collective ancestral ties to the lands and natural resources where they live or occupy or from which they have been displaced. These land and natural resources on which they depend are inextricably linked to their identities, cultures and livelihoods, as well as their physical and spiritual well-being. Despite this however, they often lack any formal 
recognition over their rights and relationships to their lands or territories and to the natural resources that are located on or beneath them.

Ironically, Indigenous Peoples own, occupy, or use a quarter of the world's surface area, and they safeguard 80 percent of the world's remaining biodiversity. Moreover, even when their customary rights to the use of their lands are at least partially recognised, they are often violated as a result of weak protection of boundaries and encroachment by external parties; against which they have little defence in view of their general lack of voice or agency within debates and policy-making processes that affect them. In this regard, Indigenous Peoples have become the victims of national development policies that target economic growth and individual income levels with the expectation that benefits would be widely enjoyed through a trickle-down process involving the entire population (World Bank).

In too many instances, such development has assumed that the assimilation of Indigenous Peoples into the cultural, social and economic systems of the dominant societies in which they live would be the most desirable outcome for both themselves and for everyone else. However, horror stories abound telling of the forced assimilation and genocide of Native North Americans and Aboriginal Australians (as well as others) throughout the 18th, 19th and 20th centuries which have often led to disastrous consequences for individuals, families and entire communities (Hoxie, 1984; Short, 2003).

Assimilation of indigenous cultures and lifestyles into their dominant societies assumes that development means all members of a society wish to follow the same social and economic models and practices. This assumption, according to Doyle and Gilbert (2015), is highly arrogant and extremely detrimental - ultimately fatal - to Indigenous Peoples' own forms of traditional economy and practices, and indeed to their very existence. This interpretation of development is premised, they say, on the idea that traditional economies and ways of life, such as nomadic hunter-gathering or subsistence farming, are outdated forms of development, which should give way to more 'advanced' industrialized approaches. The economic and social systems developed and practised by indigenous peoples for centuries are seen as obstacles to development and are categorized as 'primitive' and outdated. Some observers point to the problematic perception of Indigenous Peoples' remote, yet intact and locally sustainable traditional economies as 'failed' attempts at modernization or of "being us" (meaning urban Western culture) (Madden, 2016).

Within this development orthodoxy, the exploitation of natural resources became a common policy. Unfortunately, a disproportionate percentage of these resources are located in Indigenous Peoples' territories and the continued abrogation of their rights was seen as a necessary evil if these development ends were to be achieved. For indigenous peoples globally, the term development therefore often equated to dispossession of their lands and resources, increased deprivation and destruction and loss of their traditional livelihoods. These outcomes of a rights-denying developmental process that was imposed on them gave rise to what Indigenous Peoples refer to as development aggression, which they classify in terms of 'the three Ps':

1) Philosophies and perspectives that ignore their world views and visions;

2) Process and policies imposed on them without meaningful consultation and in the absence of consent;

3) Pervasiveness and profoundness of impacts that result from these. (Doyle and Gilbert, 2015)

The United Nations Human Reports have repeatedly highlighted that historically, for too long, Indigenous Peoples have been the victims of development whereby many initiatives are implemented by States and private actors directed against the human rights of Indigenous Peoples and environmental sustainability (UNDP). In recognition of such injustices, Indigenous Peoples' rights have been increasingly recognized through the adoption of international instruments and mechanisms, most notably, the United Nations Declaration on the Rights of Indigenous Peoples (UNDRIP) in 2007. 
The Declaration expresses concern that Indigenous Peoples have suffered from historic injustices as a result of, inter alia, the colonization and dispossession of their lands, territories and resources, thus preventing them from exercising, in particular, their right to development in accordance with their own needs and interests. It also expresses the conviction that control by Indigenous Peoples over developments affecting them and their lands, territories and resources will enable them to maintain and strengthen their institutions, cultures and traditions, and to promote their development in accordance with their aspirations and needs, as well as acknowledging that respect for indigenous knowledge, cultures and traditional practices contributes to sustainable and equitable development and proper management of the environment (UNDP, 2008).

The UNDRIP was adopted by the General Assembly by a majority of 144 states in favour, with 4 countries (Australia, Canada, New Zealand and the United States) voting against. However, these countries later reversed their position and now support the Declaration. The three countries that occupy Borneo; Indonesia, Malaysia and Brunei, all voted in its favour. However, the International Work Group for Indigenous Affairs (IWGIA) points to various challenges relating to the implementation of the UNDRIP in Borneo; e.g., concerning land rights in Malaysia and the unwillingness of the Indonesian government to fully accept the concept of indigenous peoples, who are increasingly experiencing criminalisation and violence, often related to investments in their territories (IWIGA).

\section{BORNEO}

Of the world's indigenous population, roughly $75 \%$ live in Asia, with around 65 million in Indonesia and Malaysia. Indonesian Borneo - Kalimantan province - constitutes $70 \%$ of the island - one fifth the area of Indonesia - but with only around 5\% of the country's population. Malaysian Borneo - the states of Sabah and Sarawak - occupies $60 \%$ of the nation's land area with $20 \%$ of its population. The population of Malaysian Borneo was put at 5.68 million by the 2010 census. Indonesia's 2010 census put the population of Indonesian Borneo at 13.8 million. Around 30\% of Borneo's people are said to be non-Muslim indigenous, putting the indigenous population at around 5.8 million people. There are said to be over 50 ethnic groups speaking around 170 languages and dialects. The population distribution of the island is characterised by concentrations in the coastal regions, with the majority of the indigenous people living in the interior.

Borneo is the world's third largest island and was once covered with dense tropical rainforests across its 287,000 square miles. According to WWF, Borneo is among the most biologically diverse habitats on earth, holding approximately $6 \%$ of global biodiversity (WWF). There are more 15,000 known plant species, 222 mammals (44 endemic), 420 birds (37 endemic), 100 amphibians and 394 fish (19 endemic). Since 1995, more than 400 species have been identified, with more than 50 of them completely new to science.

However, many of these species and carbon-rich ecosystems have been destroyed by logging and conversion, which increasingly threaten protected areas. The protected lowland forests of Indonesian Borneo declined by more than 56\% (>29,000 square kilometres) from 1985 to 2001 (Curran et al., 2004). Eighty percent of the rainforests in Malaysian Borneo have been heavily impacted by logging for timber extraction and oil palm plantations (Butler, 2012). According to WWF, Borneo has already lost over half its forests, and a third of these disappeared in just the last three decades.

In response to the loss of Borneo's rainforests, WWF initiated the Heart of Borneo (HoB) declaration in which the three governments of Borneo committed to securing a sustainable future for the island's highland rain forest by signing an historical agreement. Its stated intent is to ensure the effective management of forest resources and the creation of a network of protected areas, sustainably-managed forests and land-use zones across the 22 million hectares which constitute the Heart of Borneo - an area which covers almost one third of the whole island. ${ }^{7}$ The Heart of Borneo includes a million forestdwelling indigenous people and provides ecological services for at least 11 million Borneans.

\footnotetext{
${ }^{7}$ https://wwf.panda.org/knowledge_hub/where_we_work/borneo_forests/about_borneo_forests/declaration.cfm
} 
The HoB Workplan for 2018-2020 targets the need to empower local communities and Indigenous Peoples to have a stronger role in the stewardship of natural resources and sustainable development of the island. It is expected that more forests are managed sustainably through a network of these indigenous communities with the capacity to engage in decision-making, information-sharing and fundraising (WWF, 2018). To this end, WWF facilitated the formation of two indigenous community organisations, both of which have been awarded the prestigious United Nations Development Programme's Equator Prize that recognizes outstanding community efforts to reduce poverty through the conservation and sustainable use of biodiversity.

The first such organisation is FORMADAT - Forum Masyarakat Adat Dataran Tinggi Borneo (Alliance of the Indigenous Peoples of the Highlands of Borneo). This is a trans-boundary organisation encompassing communities in Sabah, Sarawak and Kalimantan. It is a grassroots initiative that aims to increase awareness and understanding of the communities of the Borneo highlands, maintain cultural traditions, build local capacity, and encourage sustainable development in the Heart of Borneo without risking the degradation of the quality of the social and natural environment. The aim of FORMADAT is to encourage sustainable development by means of community-based ecotourism, organic farming and agro-forestry, communication and information technology, and the preservation of cultural and natural heritage of the Highlands to benefit present and future generations. The organisation of FORMADAT comprised the sub-districts of Krayan and Krayan Selatan in Indonesia; and Bario, Ba' Kelalan, Long Semadoh, and Ulu Padas in Malaysia.

The second organisation is FoMMA - Forum Musyawarah Masyarakat Adat Taman Nasional Kayan Mentarang, which brings together 11 indigenous groups to advocate for the rights of communities who live on 20,000 square km of customary land in Northern Kalimantan, a large portion of which is made up of forests and rivers overlapping with the Kayan Mentarang National Park. FoMMA's communities pursue traditional forest-based local economies and protect large swaths of rainforest in an effort to mitigate climate change and retain their traditional ways of life. WWF facilitates meetings of FORMADAT and FoMMA as well as funding and supporting capacity-building training programmes for the co-management of the Kayan Mentarang National Park as well as community mapping and reforestation projects (Hitchner, 2010).

\section{UNIMAS RESEARCH}

Alongside the establishment of the HoB, a programme of action-research based in the University Malaysia Sarawak (UNIMAS) beginning in 1998 has deployed Information and Communication Technologies (ICTs) into remote and isolated indigenous communities in the Borneo's northern central highlands, which form part of the HoB. Known as eBario - as the village of Bario was the first such participating community - the programme installed telecentres ${ }^{8}$ in several indigenous communities. The intent has been to understand how to achieve sustainable human development for such communities through the deployment of ICTs. Direct impacts have delivered benefits for improved skills, incomes, health, education, cultural preservation, agriculture and social communications for participating communities. Wider impacts include influence on national policymaking and the operation of development interventions as well as providing important insights into the conduct of research that seeks to improve the lives of marginalised and underserved communities through the use of ICTs. (Harris, 2018).

Although the remoteness of Bario and associated logistical and technical challenges created several difficulties, arguably, the greater challenge came from facilitating acceptance and ultimately appropriation of the technology by the community, to whom it was almost completely unknown at the project's beginning. As Bala (2010) puts it, the social shaping of technology (SST) approach to technology-society relationships builds on two main themes: the design and implementation of ICT

\footnotetext{
${ }^{8} \mathrm{~A}$ telecentre is equipped with computers and associated equipment for shared use by a community. Its staff work to facilitate local development through the use of the technology.
} 
artefacts and systems and the implications of ICTs for individuals, organizations and society. Accordingly, the eBario project implementation adopted the Participatory Action Research (PAR) approach characterised by:

- the researchers should learn about life in Bario from the community;

- the community should learn about ICTs from the researchers;

- community members should perform major portions of the research;

- the researchers should be able to identify with the community; and

- as a team, the community-researchers should be capable of critically reflecting upon iterative cycles of action in order to achieve mutually beneficial outcomes from the project (Bala, Songan \& Harris 2008).

Throughout the twenty-year period of engagement between UNIMAS and the indigenous communities in the $\mathrm{HoB}$, the University has facilitated several ancillary projects that brought researchers into close contact with area's residents in ways that benefit both the researchers and the community, each involving the use ICTs to a greater or lesser degree. Arising from the successes of eBario, the Malaysian government supported its replication in four other rural and remote indigenous communities in Borneo (Yeo et al., 2011).

In keeping with the participatory approach adopted with the telecentre implementation projects, in 2007, UNIMAS researchers initiated a rural conference, initially called the eBario Knowledge Fair, which was later widened to the eBorneo Knowledge Fair (eBKF). The event is held biennially in one of the participating villages, bringing together community members, researchers, government officials, private sector representatives and development professionals in an environment where the residents feel comfortable and are encouraged to participate. It is an immersive experience for the visitors; breaking down any stereotypes that they may have of indigenous community life. The eBKF has been held every other year between 2007 and 2019 (Harris, 2017).

Radio Bario went on air in October 2010, becoming Malaysia's first community radio station. It broadcasts twice a day to a 15-25-kilometre radius from the eBario telecentre, in the local Kelabit language; disseminating local and national news as well as local announcements (Samani et. al., 2013).

The outcomes of the eBario initiative have been tracked regularly in conjunction with other developments within the community that have occurred since its inception and they can be contrasted with the initial conditions that the researchers found there. In 1998, the population was dwindling; communications with the outside world were rudimentary; mobile phones were not available; no one in Bario knew anything of the Internet; nobody regularly used computers; households had to generate their own electricity; agriculture sector was dependent on imported labour from East Kalimantan; there was no road access and less than one flight per day from the town of Miri, the nearest major urban centre.

Today, 22 years after the project began, ex-residents are returning to live in Bario; everyone knows and uses the Internet; computers are well-known and mobile phones are near ubiquitous; Radio Bario operates as Malaysia's first ever community radio station; a solar-farm provides 24-hour electricity; agriculture is mechanised; the highlands road network has greatly expanded, including access to Miri, from which there are upwards of three daily flights to Bario. Concurrent with these changes, the sociocultural-economic and demographic profile of Bario has also changed with return and retention of younger residents.

With easier access, tourism is now a major source of income; once scarce goods are now commonplace; households boast a wide range of electrical appliances and there are even occasional problems with road traffic. Bario has also been elevated to a sub-district, with a new administrative centre. The eBario initiative can justifiably claim some influence in bringing about these changes, either directly or indirectly (Harris, 2016). Research in Bario has even highlighted how non-users of a telecentre can derive benefits from it and that these benefits can be as significant as those derived by users. 
Furthermore, the intangible benefits enjoyed by both users and non-users can also be significant and should be included in future telecentre evaluations to obtain a richer picture of their development impact (Tabassum et al., 2019).

The eBario project is presented here as an instance of bringing in new ideas (development) and objects (ICTs) to a Borneo community that hitherto had experienced little of either. We argue that these ideas and objects have been transformed into mechanisms for extended long term networks with partners from within and beyond Borneo, which in turn have created further sources and channels of new ideas, including sustainable development and human rights for indigenous peoples; in the process connecting the residents of the HoB with issues of global concern.

eBario has focussed attention and facilitated action relating to the importance of indigenised ethnodevelopment in preserving biodiversity and combatting global warming, both of which are being blamed for the increased incidence of global virus pandemics - "the same human activities that drive climate change and biodiversity loss also drive pandemic risk through their impacts on our environment" (IPBES, 2020). Whilst the technology (object) has played a significant role in forwarding the development (idea), the participating communities have been observed building their confidence to act and their resilience towards the multiple threats that arrive with climate change or are imposed upon them from orthodox development. A better understanding of how they are able to do this can also contribute to learning that can have global significance.

In 2016, Cornell University brought its Global Citizenship and Sustainability programme ${ }^{9}$ to Sarawak in partnership with UNIMAS to focus on student engaged learning in community settings; including the highly remote and isolated Penan village of Long Lamai. Students from the two universities used community-based participatory research methods to understand community needs, explore community resilience to climate change, and collectively (with guidance from faculty and community members) develop recommendations as how best to select and implement adaptation strategies for the future to improve resiliency (Jengan et al., 2018). Between 2016 and 2018, the researchers and students collected data through discussions, meetings and interviews with the residents to examine the relationship between their culture and community resilience - particularly in the face of encroaching developments relating to globalization and climate change. Six key principles emerged about the Penan as global citizens: 1) unity, 2) fairness, 3) cohesion, 4) collective decision-making, 5) benefits to all, and 6) education and learning for advancement. The study concluded that the community's core values have kept them together and remain their only hope in withstanding uncertainties and tides of change; lessons that are applicable to other indigenous communities struggling to be resilient against both swift and ongoing perturbations (Allred et al., 2020).

Also, in 2016, researchers from Cambridge University were facilitated by UNIMAS to undertake an assessment of the indigenous community preferences for electricity services to ensure that electrification schemes are congruent with the communities' specific development pathways. The results demonstrated the social and institutional challenges in Sarawak and suggest the need for the state utility to engage with indigenous communities (van Gevelt et al., 2017).

In the years since UNIMAS began its research partnerships with indigenous communities in the $\mathrm{HoB}$, the area has become an important destination for community-based eco-tourism. Tourism in Bario grew from its accidental beginnings to becoming a mainstay of the local economy, embracing along the way many different forms, including eco-tourism, adventure tourism, cultural tourism, research tourism, and its latest manifestation, development conferencing in the form of the eBKF. The growth of tourism in the area is closely interwoven with other aspects of the social and cultural development (Harris, 2009). Residents have recognised the need to protect their forest and cultural sites in order to maintain the incomes that tourism generates (Hitchner, 2009).

\footnotetext{
${ }^{9} \mathrm{https}: / /$ psc.cornell.edu/global-citizenship-and-sustainability
} 
The research findings from eBario and related projects offer important lessons for development interventions in settings that are similar; especially for those involving ICTs but also for others. Most significantly, it is clear that the chances for desirable outcomes are increased when interventions are operated in a participatory bottom-up fashion; addressing needs that have been identified and prioritised by the community (Tarawe \& Harris, 2009). In adopting an approach that acknowledges the principles embodied by the social shaping of technology (Bala, 2010), this outcome appears intuitively correct. Yet, it cannot be assumed that the introduction of ICTs automatically leads to desirable human development outcomes. According to Trauth and Howcroft (2006), the concept of exclusion features prominently in the information society discourse where access to and knowledge of ICTs are portrayed as either exacerbating exclusion or seen as a platform to engender inclusiveness. In reality, they say, the ability of ICTs and networks to herald social change and reorganize the economy is far less radical than is often assumed.

\section{INDIGENISING DEVELOPMENT}

Apart from this uncertainty, throughout the more-than-20-year engagement with the indigenous communities in Borneo, the researchers discovered aspects of human development relating to the specifics of the lifestyles and cultures of the participating indigenous communities that differed considerably from those found elsewhere. By uncovering the residents' views of development, and learning more of their perspectives of development aggression, the concept of ethno-development or indigenised development emerged as a guide to steer the joint identification, design, implementation and evaluation of interventions.

The term ethno-development refers to development policies and processes that are sensitive to the needs of ethnic minorities and indigenous peoples (Chernela, 2012). According to Broadfield (2017), by ensuring that decision-making is in the hands of those closest to whom the decision will affect, ethnodevelopment is a paradigm that can empower indigenous peoples to redress the balance of social, political and economic power and empower community members to enact their right to develop culturally, economically and socially.

Ramos et al. (2009) contend that among the many social groups that have been historically excluded, indigenous peoples comprise one that offers great challenges to development. Although their assimilation has been a goal of the national societies that engulfed them, it is disputable whether indigenous peoples desire the type of social inclusion that development, in its many forms, can produce. At the same time, development seems irreversible, and resistance to it might have consequences far more adverse than those brought by acceptance. The best way to overcome the challenges seems to be to indigenise development: to put it to work on behalf of indigenous peoples instead of putting them to work for a model of development that is not only alien to them but that frequently does violence to their culture. The main point, they say, is not whether to accept or deny the current model of development projects imposed by the state, but to transform it into what contemporary indigenous peoples want; not to get rid of development, but to indigenise it (Ramos et al., 2009).

With the eBario and associated projects, ICTs have been convincingly demonstrated to offer opportunities for indigenised ethno-development when introduced within processes that take full account of the local socio-economic context. The outcome has been development where indigenous communities were empowered to devise, prioritize and even implement development activities of their own devising. Furthermore, it became evident that many of the core characteristics of ICTs have been shown to be conducive to the promotion and implementation of ethno - indigenised development. As Harris (2018) points out, these include:

- Improved participation in information age undertakings which allows groups to formulate their own proposals for development and to counter misinformation that threatens their implementation; 
- The democratisation of communications and new media which gives voice to those who were previously voiceless, allowing them to participate in public debates surrounding issues that affect them;

- The 'death of distance' which brings communications to the remote and isolated locations in which many indigenous peoples reside;

- Transferring agency to community-based users of ICTs accords with the established design principles that are known to foster success with information systems as well as the bottom-up approach to development that is deemed necessary for community wellbeing;

- The ability to preserve, promote, and strengthen indigenous languages and culture, which counters the perception that ICTs are driving globalisation when it is perceived as a force for cultural homogenisation.

Examples of ICTs for indigenised development that eBKF have fostered include:

- Land mapping with drones

- Language preservation

- Resolving disputes

- Agriculture entrepreneurship

- Geomorphology maps

- Community area zoning

- Art and handicrafts

- Understanding climate change impacts and their mitigation

- Community resilience

- Rural technology for connectivity

- Traditional practices for conservation

- Preserving traditional indigenous knowledge

- Stimulating grass-roots interest in local culture

- Community-based tourism

- Sustainable livelihoods

- Service learning for communities

- Digital inequality (Harris, 2018).

\section{INDIGENOUS PEOPLES AND SUSTAINABLE DEVELOPMENT}

The 2030 Agenda for Sustainable Development, adopted by all United Nations Member States in $2015^{10}$, provides a shared blueprint for peace and prosperity for people and the planet, now and into the future. At its heart are the 17 Sustainable Development Goals (SDGs), which are an urgent call for action by all countries - developed and developing - in a global partnership. They recognize that ending poverty and other deprivations must go hand-in-hand with strategies that improve health and education, reduce inequality, and spur economic growth - all while tackling climate change and working to preserve our oceans and forests. SDG13 calls for urgent action to combat climate change and its impacts and SDG15 upholds the need to sustainably manage forests and halt biodiversity loss. These two goals have particular relevance for Indigenous Peoples.

In his book The Age of Sustainable Development, Professor Jeffrey Sachs, the renowned development economist, director of the Earth Institute at Columbia University and special adviser to the UN secretary-general, explains how the world is on a collision cause with the physical environment. Whilst the SDGs will continue the fight against poverty, he says, they will also add the challenge of ensuring

\footnotetext{
${ }^{10} \mathrm{https} / / / \mathrm{sdgs}$.un.org/goals
} 
environmental sustainability, especially the key goal of curbing the dangers of human-induced climate change. His argument is that further development cannot be sustainable without protecting the environment and that the environment cannot be protected if development is not sustainable (Sachs, 2015). Sachs also points out how biodiversity determines how well ecosystems perform and therefore how well they provide vital services for humanity ${ }^{11}$.

As the UN points out ${ }^{12}$, Indigenous Peoples are among the first to face the direct consequences of climate change, due to their dependence upon, and close relationship, with the environment and its resources. Climate change exacerbates the difficulties already faced by indigenous communities including political and economic marginalization, loss of land and resources, human rights violations, discrimination and unemployment. The International Union for Conservation of Nature (IUCN) has also reported that communities who live in marginal lands and whose livelihoods are highly dependent on natural resources are among the most vulnerable to climate change. Many indigenous and traditional peoples who have been pushed to the least fertile and most fragile lands as a consequence of historical, social, political and economic exclusion are among those who are at greatest risk.

On the other hand, people living in marginal lands have long been exposed to many kinds of environmental changes and have developed strategies for coping with these phenomena. They have valuable knowledge about adapting to climate change, but the magnitude of future hazards may exceed their adaptive capacity, especially given their current conditions of marginalization (IUCN, 2008). The, United Nations Forum on Indigenous Issues ${ }^{13}$, underscores this perspective, highlighting the following examples:

- Glacial melts in the high-altitude Himalayas resulting in unreliable water sources

- Deforestation in the Amazon leading to droughts

- Loss of sea ice in the Arctic inhibiting hunting

- Mild winter weather in Finland, Norway and Sweden disrupting reindeer herding

- Rising temperatures, dune expansion, increased wind speeds, and loss of vegetation in the Kalahari negatively impacting traditional cattle and goat farming

- Rising sea levels threaten the very existence of Kiribati, a low-lying island nation in the tropical Pacific.

Observers of the impact of climate change on Indigenous Peoples are coming to the realisation that their traditional knowledge has value in facilitating greater understanding of those impacts as well as strategies for coping and adapting to changes in the environment. The currently accepted paradigm for sustainable development science is that it also requires involving non-scientists - what is called transdisciplinarity. This combines inter-disciplinarity and participatory approaches and requires reaching out to various communities as well as considering non-scientific knowledge in the research process e.g. from local and indigenous communities, user groups, the general public and non-governmental organizations. Consideration of a broader range of knowledge and in particular indigenous knowledge is critical to the credibility and legitimacy of science-policy interface mechanisms (UN, 2015).

Dinerstein et al. (2020) propose a Global Safety Net to map how expanded nature conservation addresses the dual crises of biodiversity loss and climate change. They highlight how Indigenous lands overlap extensively with the Net and argue that the sustained presence of indigenous communities within intact areas can have long-term benefits for both biodiversity and carbon storage. The International Labour Organization points out that Indigenous Peoples, with their traditional knowledge and occupations, have a unique role to play in climate action, cutting across both climate mitigation and adaptation efforts, and also just transition policies. Consequently, in order for climate action to be successful, indigenous peoples must be seen as powerful agents of change, accorded access to decent

\footnotetext{
${ }^{11} \mathrm{https}: / /$ www.youtube.com/watch?v=zsZ-sTNciKY

${ }^{12} \mathrm{https} / /$ www.un.org/development/desa/indigenouspeoples/climate-change.html

${ }^{13} \mathrm{https} / / /$ www.un.org/en/events/indigenousday/pdf/Backgrounder_ClimateChange_FINAL.pdf
} 
work opportunities and the ability to participate in the development, implementation and evaluation of sustainable policies and measures aimed at combating climate change (ILO, 2017).

The UN Global Sustainable Development Report ${ }^{14}$ highlights the Caribbean Natural Resources Institute (CANERI) comment that discussions of the science-policy interface must define science broadly, to include not only the physical and natural sciences but the social sciences as well. Local and indigenous knowledge offers an important perspective. Traditional knowledge is enriched by long term engagement with the natural environment and plant and animal life of a given local area. For example, participatory community mapping enlists local communities to map the elevation, natural resources and other characteristics of vulnerable areas such as low-lying islands and forests based on their personal and familial knowledge - collecting valuable data that could otherwise have taken years to amass. Indigenous dietary patterns can be studied to develop policy recommendations for improving health and reducing the incidence of non-communicable diseases (CANERI, 2013).

Leonarda et al. (2013) suggest that Indigenous Peoples offer alternative knowledge about climate variability and change based on their own locally developed knowledges and practices of resource use. Indigenous groups accumulate detailed baseline information about their environment to guide their resource use and management and develop worldviews and cultural values associated with this knowledge. Traditional ecological knowledge therefore plays a critical role in mediating indigenous individuals and communities' understandings of environmental changes and how these beliefs may influence future decision-making about how to go about adapting to climate change at a local level.

Environmentalists at the UN support this view, claiming that many indigenous groups had their own concepts of respect for nature and stewardship long before the conservation movement began. They have been observing environmental changes for generations; and have recognized patterns. And this is exactly the kind of knowledge and expertise needed to tackle climate change and mitigate its harmful impact. ${ }^{15}$ Additionally, the UN Development Programme (UNDP) maintains that there is a growing understanding that indigenous lands and waters represent 80 percent of the world's biodiversity, that indigenous peoples are effective stewards of these areas, and that these ecologically intact areas of the earth are a vital strategy for tackling climate change. If the Global Goals for sustainable development are to be achieved by 2030, we must recognize, celebrate, advance and safeguard the rights of indigenous peoples to govern their lands and waters. ${ }^{16}$

Despite these pronouncements, it is worth noting that the SDGs make passing reference to indigenous peoples - lumping them together with other vulnerable groups such as women, farmers, pastoralists, fishers, persons with disabilities, and children. International indigenous organisations have consistently objected to this as; i) it obscures the adversity and specifics of the issues that indigenous peoples everywhere face, and ii) it ignores the potential contributions that indigenous peoples can make towards development that is sustainable and especially to the understanding and mitigation of climate change through the traditional knowledge that they possess of their environments, which tend to represent the areas of the globe that will be most affected (Harris, 2018).

Nevertheless, in recognition of the role that Indigenous Peoples can play as stewards of the most vulnerable and most biodiverse environments in which they live, the UNDP has introduced the Equator Initiative which awards the Equator Prize biennially to indigenous communities to recognize and advance local sustainable development solutions for people, nature and resilience. Its intent is to recognize the success of local and indigenous initiatives, create opportunities and platforms to share knowledge and good practice, inform policy to foster an enabling environment for local and indigenous community action and develop the capacity of local and indigenous initiatives to scale-up their impact. ${ }^{17}$ The Equator Prize has been awarded to four indigenous groups in Borneo:

14

https://sustainabledevelopment.un.org/content/documents/1758GSDR\%202015\%20Advance\%20Unedited\%20Version.pdf

$15 \mathrm{https} / /$ www.unenvironment.org/news-and-stories/story/indigenous-peoples-and-nature-they-protect

16 https://www.undp.org/content/undp/en/home/blog/2017/5/2/Celebrating-Indigenous-Peoples-as-nature-s-stewards-.html

17 https://www.equatorinitiative.org/ 


\section{Persatuan Penduduk Uma Bawang (UBRA, Uma Bawang Residents' Association) in 2002}

This community-based organization operates in the forests of the Malaysian state of Sarawak. While the customary land rights of the association's indigenous Kayan people are recognized by the Malaysian government, many lands have not been officially demarcated, making them vulnerable to conflicting claims from outside interests. Members of the association work with GIS survey and mapping technology to compile land use maps of communally managed forests, providing a spatial basis for legally defending community land claims in court. Combined with active resistance to incursions by commercial logging and palm oil interests, including road blockades and political advocacy, and underpinned by two decades of livelihoods development, this association has been able to resist the destruction of the Kayan's traditional forest lands, and instead demonstrate their sustainable management by the local communities that directly depend on them. ${ }^{18}$

\section{FORMADAT: The Alliance of the Indigenous Peoples of the Highlands in the Heart of Borneo, in 2015}

This trans-border Indigenous Peoples alliance came together in 2004 to build on the shared historical and cultural bonds between the Lundayeh, Kelabit, Lun Bawang, and Sa'ban peoples living in the highlands of the heart of Borneo. The group aims to integrate conservation and development at the landscape level and to generate benefits for local people by preserving the rich natural and cultural diversity of the region, an area that includes the largest surviving intact forested and traditionally farmed catchment area on the island of Borneo. Farmers in the region use a traditional wet rice farming system, developed over centuries, which allows the same fields to be farmed continually and is unique in Borneo where most use shifting agriculture. The group has prioritized farming native varieties of rice and fruits, building innovative value-added supply chains to NGOs and networks such as Slow Food International. FORMADAT also works as an advocacy network that actively lobbies for greater land tenure security, Indigenous Peoples rights, and forest protection. Several member communities have conducted territorial mapping and campaigned to gain rights to their traditional lands, including collaborative management of lands inside an Indonesian national park. ${ }^{19}$

\section{Customary Community of Dayak Iban in Sungai Utik Longhouse in 2019}

Throughout a 40-year campaign to obtain legal recognition of land rights to their 9,504-hectare customary forest, the Indigenous Group of Dayak Iban Sungai Utik Long House have consistently defended their lands against illegal logging, palm oil production, and corporate interests, protecting an estimated 1.31 million tons of carbon. Known as the Sungai Utik forest guardians, the group lives in West Kalimantan in a 214-metre traditional long house that accommodates 318 people. The Dayak Iban sustainably manage their forest in accordance with customary laws $-6,000$ hectares are reserved as protected forest and 3,504 hectares are reserved for crop cultivation managed in a traditional rotation system. This management system provides the group with food, medicine, and clean water. Valuing nature and cultural integrity over temporary wealth from the sale of their land, the Dayak Iban illustrate the power of sustainable indigenous management for climate change mitigation and human wellbeing. ${ }^{20}$

FoMMA, Alliance of the Indigenous Peoples of the Kayan Mentarang National Park in 2020

Bringing together 11 indigenous groups, Forum Musyawarah Masyarakat Adat Taman Nasional Kayan Mentarang (FoMMA) advocates for the rights of communities who live on 20,000 square kilometers of customary land in Northern Kalimantan. A large portion of their ancestral lands, mainly made up of forests and rivers, overlaps with Kayan Mentarang National Park. The park was the first in Indonesia to be placed under a collaborative management arrangement. Government and indigenous authorities, represented by FoMMA, decide jointly on resource management as well as traditional access and use rights, promoting local stewardship over the park. FoMMA has supported communities to document

\footnotetext{
${ }^{18} \mathrm{https}$ //www.equatorinitiative.org/2017/05/29/persatuan-penduduk-uma-bawang-ubra-uma-bawang-residents-association/ ${ }^{19} \mathrm{https}$ ://www.equatorinitiative.org/2017/05/28/formadat-the-alliance-of-the-indigenous-peoples-of-the-highlands-in-theheart-of-borneo/

${ }^{20} \mathrm{https} / /$ www.equatorinitiative.org/2019/07/31/indigenous-group-of-dayak-iban-sungai-utik-long-house/
} 
and map over 20,000 square kilometers of indigenous territories. In 2019, they secured legal recognition for a first block of 2,500 square kilometers of customary lands under national law. FoMMA's communities pursue traditional forest-based local economies and protect large swaths of rainforest in an effort to mitigate climate change and retain traditional ways of life. ${ }^{21}$

Against the background of the realisation of the role that Indigenous Peoples play in preserving the vulnerable eco-systems in which they live, the COVID-19 pandemic has highlighted another aspect of relevance - our relationship with nature. According to Sebesvari (2020), there are two ways that our impact on the environment is increasing the threat of pandemics, such as the current coronavirus outbreak. First, with growing human settlements and land-clearing for agriculture, the transition zones between different ecosystems have grown. This leads to species from different habitats mixing and interacting with each other in new ways, providing new opportunities for diseases to jump between species, as coronavirus did. Second, the loss of biodiversity drives the emergence of zoonotic diseases. Sebesvari's hope is that the pandemic will instigate action to address ecosystem degradation and biodiversity loss through a green strategy that can support sustainable development and combat climate change. The World Economic Forum (WEF) also acknowledges that the COVID-19 pandemic is a stark reminder of our dysfunctional relationship with nature, saying studies show deforestation and loss of wildlife cause increases in infectious diseases (Quinney, 2020).

As a case in point, Lambertini et al., (2020) of WWF International cite the 1997 burning of a large area of rainforest in south-east Asia to make way for palm oil plantations. A combination of deforestation, forest fires and drought are believed to have forced hundreds of fruit bats away from their natural habitats towards fruit orchards planted in close proximity to intensive pig farms. These conditions led to the emergence of the Nipah virus, which spilled over from infected bats to pigs, and from pigs to pig farmers. Over the next two years, the disease would kill more than 100 people. This should have served as a warning, he says, arguing that our blatant disregard for the environment has pushed the natural world to its limits. Nature is currently declining globally at rates unprecedented in human history, and this is increasing our vulnerability to new diseases. Thus, outbreaks of disease are manifestations of our dangerously unbalanced relationship with nature (Lambertini et al., 2020). Blair and Avgoulas (2020) reinforce this view, claiming it is argued that the pandemic is the product of human interference with nature, whilst Collier (2020) suggests that real wealth should be measured by the quality of our relationship with the natural world.

This picture of the startling deterioration of humanity's relationship with nature sits in stark contrast to the enduring, often spiritual, association that Indigenous Peoples have with their environment, as exemplified by the Equator Prize winners in Borneo. The implication underlines the suggestion that the rest of us have much to learn from them in our quest for what is being termed the post-COVID "new normal" for our future social, cultural and economic well-being, not only in terms of the relationship but how it is manifested in daily life. As Petit (2020) indicates, quoting an indigenous leader, "the resilience that lives amongst indigenous people is important for humanity right now."

According to Carr (2020), Indigenous Peoples offer untapped potential for understanding how we are shaping resilient solutions to COVID-19 and similar threats in the future. Indigenous-informed approaches would positively contribute to transforming business, health and education for a more positive global society. According to the WEF, half of the world's GDP is highly or moderately dependent on nature. For every dollar spent on nature restoration, at least $\$ 9$ of economic benefits can be expected. A focus on nature can help us understand where pandemics come from and how the socioeconomic fallout from the crisis could be mitigated (Quinney, 2020).

\section{CONCLUSION}

The eBario project that introduced ICTs into remote and isolated indigenous communities in Borneo won numerous international awards and was influential in advising the Malaysian government in its

\footnotetext{
${ }^{21} \mathrm{https}$ //www.equatorinitiative.org/2020/06/04/forum-musyawarah-masyarakat-adat-taman-nasional-kayan-mentarang/
} 
policies for bridging the digital divide by making internet access available to underserved communities throughout the country (Yeo et al., 2011). In doing so, it evolved from an exotic novelty to the national norm, in large part derived from the project's research lessons that emphasized the importance of the social shaping of technology to its implementation (Bala, 2010). As an important by product of this, the researchers uncovered the complex relationship that the indigenous residents of Borneo have had with orthodox processes of national development, at the same time recognising that similar conditions exist for Indigenous Peoples around the globe.

The eBario and associated projects have demonstrated how objects and ideas have been indigenised and appropriated by isolated communities in the Heart of Borneo, allowing them to decide, debate, choose and question development proposals and even to implement their own. Local institutions played key roles in the process, underscoring local practices of inclusiveness and participation, revealing how highvalue socio-economic development can be attained without needing to shift from traditional lifestyles.

Accordingly, it has become possible to extrapolate the findings to a far wider audience, not the least through the involvement of one member of the research team in similar NGO and government sponsored interventions across 15 Asian countries aimed at the use of ICTs for indigenised development and alleviating rural poverty. ${ }^{22}$ Beyond even this though, with the onset of global warming, plus the advent of the SDGs with their imperative for environmental protection, plus the arrival of the COVID-19 pandemic, the concept of indigenised, or ethno-development, along with the role that ICTs can play in bringing it about, as well as the role of Indigenous Peoples in protecting the environment and the value of their traditional knowledge, are all now brought to centre-stage. As Dinerstein et al., (2020) put it, addressing indigenous land claims, upholding existing land tenure rights, and resourcing programs on indigenous-managed lands could help achieve biodiversity objectives on as much as one-third of the area required by their Global Safety Net, which reaffirms their role as essential guardians of nature.

Unlike many politicians and corporate heads, Indigenous Peoples are already motivated and mobilised towards environmental protection and mitigating the effects of global warming. It is time to acknowledge these facts by guaranteeing the full potential of the Heart of Borneo agreement; by fully respecting the UN Declaration on the Rights of Indigenous Peoples; and by incorporating traditional indigenous knowledge into western science and science-policy interface mechanisms. Humanity and the planet would only benefit by doing so. Global events that are currently unfolding highlight the criticality of resolute action towards the achievement of the SGDs, bringing every available resource into play. Among them, we need genuine realisation - mainstreaming - of Indigenous Peoples' rights along with vigorous support for their role as custodians of the environment and a departure from the failed notions of development that have plagued them for far too long.

${ }^{22}$ See http://www.rogharris.org/ 


\section{REFERENCES}

Allred, S., Harris, R. W., Zaman, T., Kulathuramaiyer, N., and Jengan, G. (2020). Cultural Resilience in the Face of Globalization: Lessons from the Penan of Borneo, Ecology and Society, forthcoming.

Bala, P. and Songan, P. (2020). Building Capacity at the Local Level for a Knowledge Society: Experience Learned from the Implementation of the eBario Project. https://www.researchgate.net/publication/344208053_Building_Capacity_at_the_Local_Level_for_a_ Knowledge_Society_Experience_Learned_From_the_Implementation_of_the_eBario_1_Project

Bala, P. (2010). Social Shaping of Technologies for Community Development: Redeployment of Information Communication Technologies among the Kelabit in Bario of the Kelabit Highlands. In J. Martin and L. Hawkins (Eds.), Information communication technologies for human services education and delivery: Concepts and cases (pp. 201-214). IGI Global. https://doi.org/10.4018/978-1-60566-7355.ch013

Bala, P., Harris, R.W., and Songan, P. (2008). eBario Project: In Search of a Methodology to Provide Access to Information Communications Technologies for Rural Communities in Malaysia. In C. Van Slyke (Ed.), Information Communication Technologies: Concepts, Methodologies, Tools, and Applications (pp. 826-839). https://doi.org/10.4018/978-1-59904-949-6.ch053

Blair, W. and Avgouleas, E. (2020, Oct 21). How spatial finance can boost the climate change fight through better environmental predictions, South China Morning Post. https://www.scmp.com/business/article/3106313/how-spatial-finance-can-boost-climate- changefight-through-better

Broadfield, K. (2017). Ethno-development: Indigenous development in Indigenous hands [Bachelor dissertation, James Cook University]. https://doi.org/10.13140/RG.2.2.16098.43203

Butler, R. (2008, June 12). A Desperate Effort to Save the Rainforest of Borneo, Yale Environment 360. https://e360.yale.edu/features/a_desperate_effort_to_save_the_rainforest_of_borneo

CANERI - Caribbean Natural Resources Institute Policy Brief No. 15 (2013) and Science-policy interface in Small Island Developing States, expert meeting, St. Lucia, 16-18 March 2015

Carr, A. (2020). COVID-19, Indigenous peoples and tourism: a view from New Zealand. Tourism Geographies, 22(3), 491-502. https://doi.org/10.1080/14616688.2020.1768433

Chernela, J. M. (2012). Indigenous rights and ethno-development: The life of an indigenous organization in the Rio Negro of Brazil, Tipiti, 9, 91-120.

Collier, B. (2020, June 30). Covid-19 and our relationship with nature. The Ecologist: Informed by Nature. https://theecologist.org/2020/jun/30/covid-19-and-our-relationship-nature

Curran, L.M., Trigg, S.N., McDonald, A.K., Astiani, D., Hardiono, Y.M., Siregar, P., Caniago, I. and Kasischke, E. (2004). Lowland forest loss in protected areas of Indonesian Borneo, Science, 303(5660), 1000-1003. https://doi.org/10.1126/science.1091714

Dinerstein, E., Joshi, A. R., Vynne, C. Lee, A. T. L., Pharand-Deschênes, F., França, M., Fernando, S., Birch, T., Burkart, K., Asner, G. P. and Olson, D.A. (2020, September 4). A 'Global Safety Net' to reverse biodiversity loss and stabilize Earth's climate. Science Advances, 6(36), 1-13. https://advances.sciencemag.org/content/6/36/eabb2824.full 
Doyle, C. and Gilbert, J. (2015, January 20). Indigenous peoples and globalization: From 'development aggression' to 'self-determined development'. SSRN Electronic Journal. https://ssrn.com/abstract $=2552408$

Harris, R.W. (2016, May 22). eBario undergoes rebranding. Borneo Post. https://www.theborneopost.com/2016/05/22/ebario-undergoes-rebranding/

Harris, R.W., Ramaiyer, N.A.N.K. and Tarawe, J. (2018) The eBario story: ICTs for rural development (pp.63-68). 2018 International Conference on ICT for Rural Development (IC-ICTRuDev), Bandung Regency, Indonesia. https://doi.org/10.1109/ICICTR.2018.8706855

Harris R.W. (2017), The eBorneo Knowledge Fair: Community engagement for impact. UNIMAS Publisher.

Harris, R.W, (2009) Tourism in Bario, Sarawak, Malaysia: A case study of pro-poor community-based tourism integrated into community development. Asia Pacific Journal of Tourism Research, 14(2), 125135. https://doi.org/10.1080/10941660902847179

Harris, R.W. (2018, August 6-8). Indigenised and indigitised: Technology for development among Borneo's indigenous peoples. 14th International Borneo Research Council Conference, Translating the Past, Envisioning the Future. Kuching, Malaysia.

Hitchner S.L. (2010). Heart of Borneo as a 'Jalan Tikus': Exploring the links between indigenous rights, extractive and exploitative industries, and conservation at the World Conservation Congress 2008. Conservation and Society, 8(4), 320-330.

Hitchner, S.L., Apu, L.A., Tarawe, L., Galih S. and Yesaya, E. (2009). Community-based transboundary ecotourism in the Heart of Borneo: A case study of the Kelabit Highlands of Malaysia and the Kerayan Highlands of Indonesia. Journal of Ecotourism, 8(2), 193-213. https://doi.org/10.1080/14724040802696064

Hoxie, F. (1984). A final promise: The campaign to assimilate the Indians, 1880-1920. University of Nebraska Press.

IPBES. (2020). Intergovernmental Science-Policy Platform on Biodiversity and Ecosystem Services, Media Release. Escaping the 'Era of Pandemics': Experts warn worse crises to come. https://ipbes.net/pandemics

International Labour Organization (ILO). (2017). Indigenous peoples and climate change: From victims to change agents through decent work. https:/www.ilo.org/wcmsp5/groups/public/---dgreports/-gender/documents/publication/wcms_551189.pdf

IUCN. (2008, March). Indigenous and Traditional Peoples and Climate Change. https://www.iucn.org/downloads/indigenous_peoples_climate_change.pdf

IWGIA. https://www.iwgia.org/en/malaysia/3429-iw2019-malaysia.html

IWGIA. https://www.iwgia.org/en/indonesia.htm.

Jengan, G., Allred, S., Somchanhmavong, A.K., Harris, R., and Zaman, T. (2018). Using visual charting to explore indigenous community resilience in Bario and Long Lamai, Sarawak, Malaysia. The Journal $\begin{array}{llll}\text { of Development } & \text { Communication, } & 27(2), & 14 .\end{array}$ http://jdc.journals.unisel.edu.my/ojs/index.php/jdc/article/view/30 
Lambertini, M., Maruma, E. and Neira, M. (2020, June 17). Coronavirus is a warning to us to mend our broken relationship with nature. The Guardian. https://www.theguardian.com/commentisfree/2020/jun/17/coronavirus-warning-broken-relationshipnature

Leonarda, S., Parsonsa, M., Olawsky, K., and Kofoda, F., (2013) The role of culture and traditional knowledge in climate change adaptation: Insights from East Kimberley, Australia. Global Environmental Change, 23(3), 623-632. https://doi.org/10.1016/j.gloenvcha.2013.02.012

Madden, B. (2016), (Un)Becoming teacher of school-based Aboriginal education: Early career teachers, teacher identity, and Aboriginal education across institutions [PhD Thesis, The University of British Columbia]. https://open.library.ubc.ca/cIRcle/collections/ubctheses/24/items/1.0314570

Petit, S. (2020, April 29). How indigenous people are being affected by Coronavirus - and why it's time for a new normal. People. https://people.com/human-interest/come-back-stronger-coronavirusnick-tilsen/

Quinney, M. (2020, April 14). COVID-19 and nature are linked. So should be the recovery. World Economic Forum. https://www.weforum.org/agenda/2020/04/covid-19-nature-deforestation-recovery/

Ramos, A.R., Osório, R.G. and Pimenta, J. (Eds.) (2009). Poverty in Focus: Indigenising Development, 17, International Policy Centre for Inclusive Growth, UNDP. https:/www.un.org/esa/socdev/unpfii/documents/IPCPovertyInFocus17.pdf

Sachs, J.D. (2015). The Age of Sustainable Development. Columbia University Press.

Samani, M.S., Bala, P., Maliki, J. and Harris, R.W. (2013). Bario Community Radio: Engaging people making news (pp. 1-6). 2013 8th International Conference on Information Technology in Asia (CITA), Kota Samarahan, Malaysia. https://doi.org/10.1109/CITA.2013.6637565

Sebesvari, Z. (2020, July 8). How to improve our relationship with nature after Coronavirus. Our World: United Nations University. https://ourworld.unu.edu/en/how-to-improve-our-relationship-with-natureafter-coronavirus

Short, D. (2003). Reconciliation, assimilation, and the indigenous peoples of Australia. International Political Science Review, 24(4), 491-513. https://doi.org/10.1177/01925121030244005

Tabassum G. Kulathuramaiyer, N., Harris, R. W. and Yeo, A. W. (2019). The direct and the intangible impacts of a telecentre on a rural community. The Electronic Journal of Information Systems in Developing Countries, 85(3), 1-15. https://doi.org/10.1002/isd2.12087

Tarawe, J. and Harris R.W. (2009) Stories from eBario (pp.109-129). In E. Alampay (Ed.), Living the Information Society in Asia. Institute of Southeast Asian Studies.

Trauth, E.M., and Howcroft, D. (2006). Social inclusion and information systems field: Why now? (pp. 3-12). In E.M. Trauth, D. Howcroft, T. Butler, B. Fitzgerald and J. DeGross (Eds.), IFIP International Federation for Information Processing, Volume 208, Social inclusion: Societal and organizational implications for information systems. Springer.

UN. (2015). Global Sustainable Development Report: 2015 Edition Advanced Unedited Version. https://sustainabledevelopment.un.org/content/documents/1758GSDR\%202015\%20Advance\%20Une dited\%20Version.pdf

UNDP. (2008). United Nations Declaration on the Rights of Indigenous Peoples. https://www.un.org/esa/socdev/unpfii/documents/DRIPS_en.pdf 
van Gevelt, T., Canales C. H., George, F. and Zaman, T. (2017). Indigenous community preferences for electricity services: Evidence from a choice experiment in Sarawak, Malaysia. Energy Policy, 108, 102-110. https://www.sciencedirect.com/science/article/abs/pii/S0301421517303452\#!

World Bank. (2020, October 1). https://www.worldbank.org/en/topic/indigenouspeoples

WWF. (2018). The Heart of Borneo Workplan 2018-2020 https://issuu.com/hobgi/docs/hob_factsheet_2018_insert_printer

WWF. (n.d.). https://www.worldwildlife.org/places/borneo-and-sumatra

Yeo, A.W., Hazis, F. S., Zaman, T., Songan, P. and Khairuddin A.H. (2011). Telecentre Replication Initiative in Borneo Malaysia: The COERI Experience. Electronic Journal of Information Systems in Developing Countries, 50(3), 1-15. https://onlinelibrary.wiley.com/doi/pdf/10.1002/j.16814835.2012.tb00353.x 